\title{
Transposition
}

Musique et Sciences Sociales

$8 \mid 2019$

Musique : patrimoine immatériel ?

\section{Jane F. Fulcher, Renegotiating French Identity: Musical Culture and Creativity in France During Vichy and the} German Occupation

New York, Oxford University Press, 2018

\section{Christopher Moore}

\section{(Q) OpenEdition}

\section{Journals}

Édition électronique

URL : http://journals.openedition.org/transposition/2988

DOI : 10.4000/transposition.2988

ISSN : $2110-6134$

Éditeur

CRAL - Centre de recherche sur les arts et le langage

Référence électronique

Christopher Moore, « Jane F. Fulcher, Renegotiating French Identity: Musical Culture and Creativity in France During Vichy and the German Occupation », Transposition [En ligne], 8| 2019, mis en ligne le 15 septembre 2019, consulté le 17 décembre 2020. URL : http://journals.openedition.org/transposition/ 2988 ; DOI : https://doi.org/10.4000/transposition.2988

Ce document a été généré automatiquement le 17 décembre 2020.

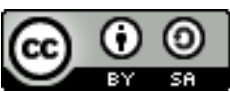

La revue Transposition est mise à disposition selon les termes de la Licence Creative Commons Attribution - Partage dans les Mêmes Conditions 4.0 International. 


\section{Jane F. Fulcher, Renegotiating French Identity: Musical Culture and Creativity in France During Vichy and the German Occupation}

New York, Oxford University Press, 2018

\section{Christopher Moore}

\section{RÉFÉRENCE}

Jane F. Fulcher, Renegotiating French Identity: Musical Culture and Creativity in France During Vichy and the German Occupation, New York, Oxford University Press, 2018, 490 p.

1 This book is the fourth installment in Jane Fulcher's ambitious, chronologicallyorganized project of examining music in France and the way that it has been created, interpreted, understood and deployed within ever-shifting political contexts. ${ }^{1}$ In this volume she tackles what is arguably the most complex and contentious political moment of them all: the defeat of France and its subsequent partial, then complete, occupation by Nazi Germany. As such, questions of resistance and collaboration in the context of rapidly changing political realities and cultural expectations dominate this volume. The author chooses to give focus to her narrative by providing five cases that represent unique pathways through the conflict and its political uncertainties. Four chapters are thus devoted to the personal choices and professional strategies of specific composers: Pierre Schaeffer, Arthur Honegger, Francis Poulenc, and Olivier Messiaen respectively, while an initial stage-setting chapter examines Vichy-era performances of Debussy's Pelléas et Mélisande and their possible meanings while concentrating on the figure of the conductor Roger Désormière.

2 Throughout her project, Fulcher has consistently drawn on the work of French sociologist Pierre Bourdieu to pose the theoretical scaffolding that informs both her 
working methods and interpretative strategies. ${ }^{2}$ Bourdieu's work, of course, has been especially relevant to recent work in popular music studies, where it has been employed to help understand how the social impacts musical creativity, production and interpretation. Despite Bourdieu's broad influence within the field of the sociology of music, and its (at times distilled) appearance in musicological work that Fulcher's study ostensibly belongs to, recent critical work has increasingly pointed out the limitations of bourdieusian paradigms as they relate to the social study of music. ${ }^{3}$ Indeed, Bourdieu's sociological lens frequently places aesthetic objects in a thoroughly reductive light: art is seen as but another product of human activity that can be explained away as one of so many tools for the legitimization of political power or as the inevitable (though perhaps unwitting) result of various societal forces.

3 When reading Fulcher's book it is difficult not to come to similar conclusions. Here, all musical endeavour and reception is thoroughly explained and justified in terms of quickly evolving political exigencies. A key consideration in her study is an emphasis on Vichy as a "shifting construction" (p. 10) which, while seeking to exclude undesirables (primarily Jews and Freemasons) from the social fabric as early as 1940, is still best conceived as an unstable and evolving entity whether concerning the French governing powers' relationship with the Germans, the internal politics of Vichy itself or the relationship of power with the cultural field. Fulcher invites the reader to become sensitized to the internal divisions and developments at Vichy: the struggles and machinations at the upper reaches of power (Pétain, Laval, and Darlan) and the role of ministers and sub-ministers of the Ministry of National Education that included the field of music in its mandate throughout the period. Fulcher contends that Vichy did not have a unified, monolithic cultural agenda (p. 34). While Maréchal Pétain's National Revolution did invite a tendency towards folklorism, Fulcher, following Julian Jackson, argues that Vichy did not employ a "consistent nor prescriptive agenda for culture." (p. 34). As the book's title implies, Fulcher argues that French culture and identity (including musical) underwent a series of negotiations and renegotiations throughout the period. The volatility of these negotiations was heightened by the stakes and the numerous groups identified by Fulcher who sought to lay a claim on French culture. These included not only the Germans and Vichy partisans, but also within the latter, various individuals of influence who sought entente with the enemy, and/or various levels of collaboration. Resistance networks also sought to give voice to a particular expression of French identity, one that attempted to subvert Vichyist aesthetic orientations in subtle yet meaningful ways. For Fulcher these negotiations were both fluid and dialogic: they responded to the changing nature of the Occupation, its policies, and French attitudes towards them just as they were circumscribed by the ideologies in play and the evolving specificities of the unique political situation in which the French found themselves.

As such, Fulcher's book exercises a focussed reading of works and their composers through the primary lens of their political efficacy and cultural appropriateness. Success and failure in this context, one must conclude, relies not on questions of craft or aesthetics, but rather on the ability of a work or an artist to function as a form of cultural capital that can buttress competing ideologies and claims to political power. For example, Fulcher regards Vichy-period performances of Pelléas et Mélisande (Chapter 2) in terms of how they responded to and articulated specific cultural and political agendas. Resistant groups, partisans of Vichy as well as Nazi collaborators all sought, according to Fulcher, to "reinscribe" Debussy's work according to their own, 
rapidly changing, political priorities. Pro-German Vichy emphasized parallels between Debussy's work and the musical language of Wagner and highlighted its ties to romanticism; resistance writing on Debussy and the opera highlighted rather the work in a French nationalist vein, and thus rearticulated arguments that had already emerged during WWI. Fulcher views these opposing fantasies as having been manifest even within specific aspects of musical performance practice. She claims, for instance, that conductor Roger Désormière's war-time interpretation of Pelléas sought to minimize Wagnerian taint through judicious musical decisions relating to tempo, vocal style, and orchestral voicing that ostensibly foregrounded the "national" and the "traditional" in Debussy's work. As such Désormière musically acted upon his resistance ideals, albeit subtly, while gesticulating on the conductor's podium.

5 Some readers may feel uncomfortable with these last, specifically musicological types of claims, particularly given that no stated methodology has been articulated that would allow for them to be verified. Indeed, troublesome in her method is Fulcher's tendency to propose as fact that which can only be viewed, at least within this current state of research, as tentatively interpretative. Take for instance this case of Désormière: would it not be necessary to propose a broader context of understanding for his conducting style to make such claims? Perhaps Désormière's ideas about tempo, vocal style and orchestral voicing reveal consistencies across his career. How would this challenge or problematize the author's claims about his musical resistance in this particular context? And this, I would argue, is where Bourdieu's model reveals some of its limitations; personal agency, aesthetic choices, and, dare I say, the magic of craftmanship have little value in a framework that reduces everything to the articulation of distinct political positions. Approaching music solely through this interpretative lens leads to necessarily deterministic readings.

6 As such, the chapter the least concerned with interpretatively fixing political to musical intent and more concerned with social interactions emerges perhaps as the book's most successful. Fulcher's examination of Pierre Schaeffer's war-time career (Chapter 3, "From the legal to the illegal: Schaeffer's journey toward resistance and artistic exploration") is a welcome addition to research in English about a composer better known for his post-war activities, in particular his founding of the Groupe de Recherche de Musique Concrète in 1951. Fulcher provides rich context to account for Schaeffer's navigation of the period. She examines his early enthusiasm for Vichy and his involvement with Radio-Jeunesse and Jeune France, initiatives that were both explicitly tied to the propagandistic energies serving to buttress Maréchal Pétain's "révolution nationale." At first enthusiastic for the creative possibilities offered by a regime in flux, Schaeffer would later be sanctioned for inappropriate programming and led to revaluate his involvement within Vichyist administrative structures in light of his concerns regarding his own collaborationist compromises.

7 This book is the result of deep engagement with a broad array of sources, exemplified most clearly by its 1,198 footnotes and twenty-nine-page bibliography (notes, bibliography and index account for $28 \%$ of the entire volume). This is certainly impressive, but it also obscures a fundamental flaw: the almost complete lack of engagement with German-language sources from this period. Indeed, reading this study one could at times almost forget (despite the sinister photo of the Palais Garnier decorated in swastikas that illustrates the book's sleeve jacket) the heavy hand of German administration on French musical life during this period. While Fulcher pays 
close attention to political developments among Vichy's leaders, the reality of the policies of the German occupying forces to which they were increasingly bound is never given necessary explication or consideration. For those interested in such questions, Karine Le Bail's 2016 study, La musique au pas: Être musicien sous l'Occupation, provides an indispensable complement to Fulcher's book. ${ }^{4}$ Indeed, Renegotiating French Identity pays little attention to the plight of Jewish musicians and composer in terms of antisemitic laws and their influence on musical institutions (including their progressive exclusion from the radio, conservatories, theatres and concert halls). And ultimately, by choosing to focus on six male classical musicians, at least five of whom had known various levels of success, even fame, during the interwar years, Fulcher offers a musical profile of war-time France that is definitely lacking, from a sociological point of view, in any noteworthy form of intersectional variety. What of the musicians whose lack of prestige did not allow a relatively comfortable path through this sinister period? What of those who lost their jobs thus allowing others to gain rare levels of cultural influence? What of the other forms of music - chanson, jazz - that equally participated in the ongoing "renegotiations" of this period? Ultimately, Fulcher's choice of her main cast of characters participates in its own form of "reinscription": one that reasserts the primacy of the stories and perspectives of a handful of cultural elites in the historical articulation of a concept so broad as that of "French identity." As such, it cannot stand as a definitive account of this period and its music, and one hopes, with the increasing availability of archival collections and the expansion of appropriate theoretical frameworks that further work will follow that will serve to complement this nonetheless impressive and thought-provoking account.

\section{NOTES}

1. See also FULCHER, Jane F., The Nation's Image: French Grand Opera as Politics and Politicized Art, Cambridge University Press, 1987; id., French Cultural Politics and Music from the Dreyfus Affair to the First World War, Oxford University Press, 1999; id., The Composer as Intellectual: Music and Ideology in France 1914-1940, Oxford University Press, 2005.

2. See also JOHNSON, Victoria, FULCHER, Jane F. and ERTMAN, Thomas (eds.), Opera and Society in Italy and France from Monteverdi to Bourdieu, Cambridge University Press, 2007.

3. For an overview as it relates to the study of music, see PRIOR, Nick, "Critique and Renewal in the Sociology of Music: Bourdieu and Beyond," Cultural Sociology, vol. 5, nº 1, 2011, p. 121-138.

4. LE BAIL, Karine, La musique au pas: Être musicien sous l'Occupation, Paris, CNRS Éditions, 2016. 


\section{AUTEUR}

\section{CHRISTOPHER MOORE}

Christopher Moore is associate professor of musicology at the University of Ottawa where he teaches undergraduate and graduate courses in both English and French. His research specializes in French music of the twentieth century. His writings have been published in The Musical Quarterly, 19th-Century Music, The Journal of Musicological Research, Music \& Politics; Intersections: Canadian Journal of Music, the Cahiers de la société québécoise de recherche en musique as well as in several edited collections. He is the co-editor of two books both published in 2018: Music Criticism in France 1918-1939: Authority, Advocacy, Legacy (with Barbara Kelly) and Music \& Camp (with Philip Purvis). In 2012 he was the recipient of the Philip Brett Award administered by the LGBTQ study group of the American Musicological Society. He is currently preparing a monograph on music and crisis in 1930s France. 